\title{
Sociocultural and environmental benefits from family orchards in the Central Highlands of Mexico
}

\begin{abstract}
José Carmen García Flores ${ }^{1}$ Jesús Gastón GutiérRez Cedillo ${ }^{2}$ Miguel Ángel Balderas Plata ${ }^{2}$ Maria Raimunda ARAújo SANTANa ${ }^{3}$
\end{abstract}

${ }^{1}$ Universidad Autónoma del Estado de México (UAEM) Faculty of Chemistry Master in Environmental Sciences Paseo Colón, esquina Tollocan, Toluca México. C.P. 50100

Mexico

2 Universidad Autónoma del Estado de México (UAEM)

Faculty of Geography

Cerro de Coatepec S/N, Ciudad Universitaria,Toluca

México. C.P. 50100

Mexico

${ }^{3}$ Doctor in Ecology Sciences and Sustainable Development San Cristóbal de las Casas, Chiapas México C.P. 29200 Mexico

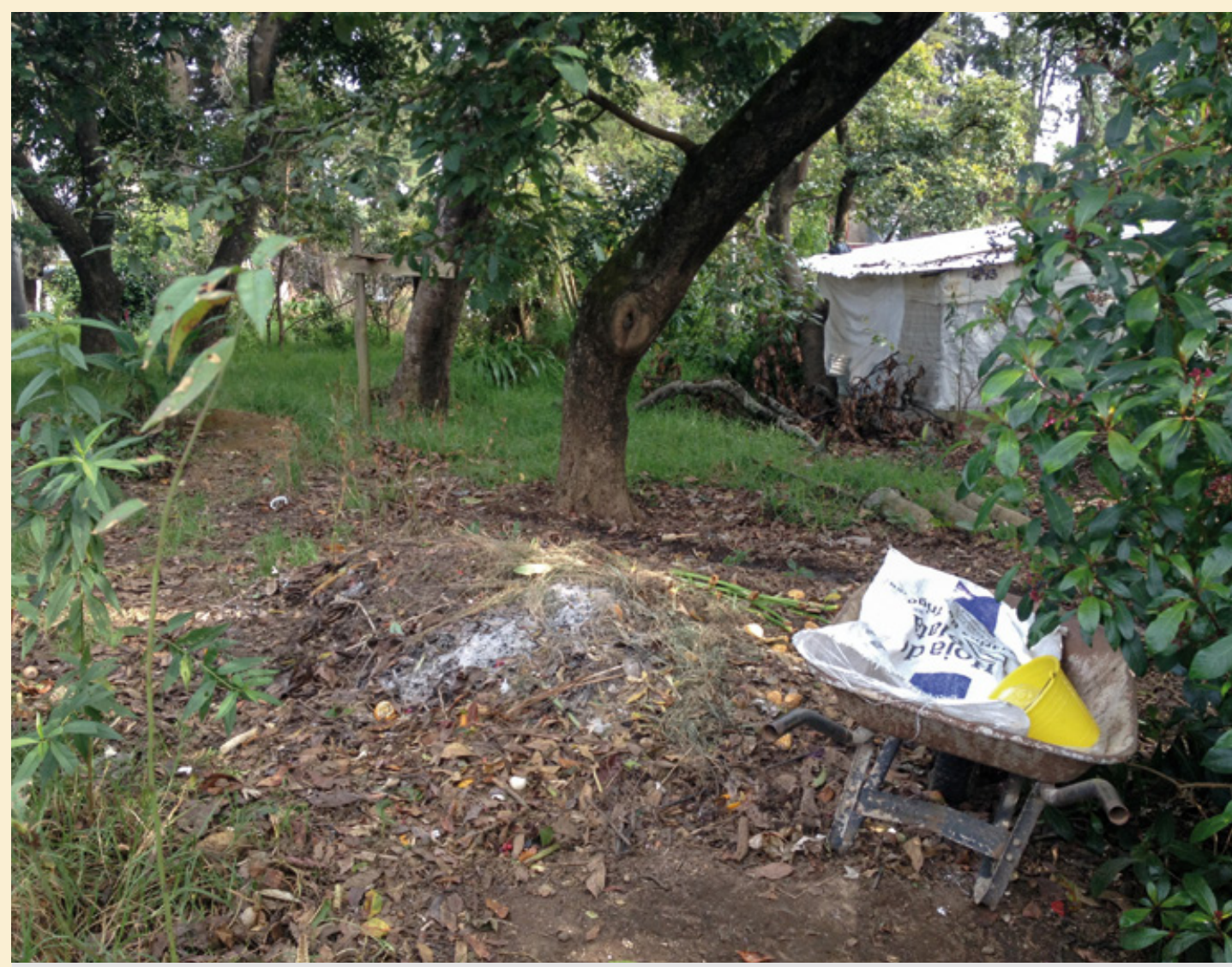

Photo 1.

Direct composting practice at the foot of trees. Photo J. García. 


\section{RÉSUMÉ}

\section{BÉNÉFICES SOCIOCULTURELS ET ENVIRONNEMENTAUX DES VERGERS FAMILIAUX DES HAUTS PLATEAUX DU MEXIQUE}

Cette étude vise à analyser les perceptions des agro-écosystèmes sur le plan socioculturel et environnemental parmi les propriétaires de vergers familiaux situés dans la zone de transition écologique de l'État de Mexico. La méthodologie comporte trois étapes : 1) caractérisation géographique des localités et des agro-écosystèmes ; 2) analyse des bénéfices sociaux des vergers ; 3) potentiel des vergers et problèmes rencontrés. L'enquête s'est déroulée sur douze localités situées dans trois municipalités de l'État de Mexico, à l'aide d'entretiens semi-structurés complétés par des observations directes sur le terrain. Les vergers familiaux sont une source de nombreux bénéfices sociaux, environnementaux, écologiques et culturels : ils contribuent au bien-être des familles par la production de fruits, de condiments et de plantes utilisées dans diverses cérémonies, récoltées pour l'autoconsommation, la vente ou le troc. Ces vergers sont également une source de bois de feu, de bois de construction, de piquets et d'ornements. Ils sont ainsi à considérer comme des agro-écosystèmes de grande importance et dont le fonctionnement repose sur des relations complexes entre l'ensemble de leurs composantes. Les bénéfices socioculturels et environnementaux de ces agro-écosystèmes productifs aux fonctions multiples peuvent être un atout considérable pour la réussite de stratégies de cohésion sociale et de sécurité alimentaire en milieu rural, tout en contribuant à la préservation des ressources naturelles de la région.

Mots-clés : vergers familiaux, bénéfices socioculturels, familles rurales, bénéfices environnementaux, agro-écosystèmes, Mexique

\section{ABSTRACT}

\section{SOCIOCULTURAL AND ENVIRONMENTAL BENEFITS FROM FAMILY ORCHARDS IN THE CENTRAL HIGHLANDS OF MEXICO}

The aim of this study was to analyze perceptions of agroecosystems in terms of their sociocultural and environmental benefits among owners of family orchards in the State of Mexico's ecological transition zone. A 3-stage methodology was used: 1) geographic characterization of localities and agroecosystems; 2) analysis of social benefits from orchards; 3) analysis of the potential of family orchards and problems encountered. The investigation was conducted in twelve localities belonging to three municipalities in the State of Mexico, using semi-structured interviews complemented by direct observations in the field. Family orchards provide multiple social, environmental, ecological and cultural benefits: they contribute to the wellbeing of families as a rich source of edibles, condiments and ceremonial plants for home consumption, sale or barter. These orchards are also used for small-scale animal breeding as well as for fuelwood, building materials, fencing materials and ornaments. Family orchards should therefore be considered as important agroecosystems, in the knowledge that they function through complex relationships between all their components. The sociocultural and environmental benefits provided by these productive multifunctional agroecosystems could make important contributions to social cohesion and food security strategies for rural families, while also helping to preserve the region's natural resources.

Keywords: family orchards, sociocultural benefits, rural families, environmental benefits, agroecosystems, Mexico.

\section{RESUMEN}

\section{BENEFICIOS SOCIOCULTURALES Y AMBIENTALES DE LOS HUERTOS FAMILIARES EN EL ALTIPLANO MEXICANO}

El objetivo de este estudio era analizar las percepciones de los agroecosistemas, en su dimensión sociocultural y ambiental, entre los propietarios de huertos familiares ubicados en la zona de transición ecológica del Estado de México. La metodología comprendía tres etapas: 1) caracterización geográfica de localidades y agroecosistemas; 2) análisis de los beneficios sociales de los huertos; y 3) evaluación del potencial de los huertos y problemas encontrados. La investigación se llevó a cabo en doce localidades de tres municipios del Estado de México mediante entrevistas semiestructuradas completadas con observaciones directas de campo. Los huertos familiares proporcionan múltiples beneficios sociales, ambientales, ecológicos y culturales: contribuyen al bienestar de las familias procurando alimentos, condimentos y plantas ceremoniales para autoconsumo, venta o trueque. Asimismo, estos huertos proporcionan leña, madera de construcción, postes para vallas y adornos. Así pues, los huertos familiares deben ser considerados como agroecosistemas de gran importancia con un funcionamiento basado en complejas relaciones entre todos sus componentes. Los beneficios socioculturales y ambientales de estos agroecosistemas productivos multifuncionales pueden contribuir de modo significativo al éxito de las estrategias de cohesión social y seguridad alimentaria en medios rurales, ayudando al mismo tiempo a preservar los recursos naturales de la región.

Palabras clave: huertos familiares, beneficios socioculturales, familias rurales, beneficios ambientales, agroecosistemas, México. 


\section{Introduction}

Family orchards, which conserve a wide variety of crops, have been developed over hundreds of years by peasant and indigenous communities (Albuquerque et al., 2005; FAO, 2005). These areas contain trees, shrubs, vegetables, tubers, edible roots and herbs which provide foodstuffs, condiments and medicines. They are a combination of useful species for family consumption (GTZ, 2008; Rivas and Rodriguez, 2013). This has been achieved through adaptation to the location, cultivation techniques, climatic conditions and the soil. They are sources of products and income throughout the year, even without using industrialized agricultural inputs (FAO, 2005; GTZ, 2008). The composition and use of crops vary depending on the living conditions and family needs in rural areas (Lok, 1998; GTZ, 2008). They are sustainable agroecosystems developed by generations (Altieri and Nicholls, 2013); ecological, agronomic, cultural, social and physical processes take place within them (Nair, 1993; Rivas, 2014).

However, these agroecosystems entail environmental and sociocultural problems, including the existence of tree pests, inadequate or no systematic pest control, failure to plant new trees and deficient upkeep activities, causing a decrease in their productivity. Likewise, the loss of traditional knowledge for family orchard management, the reduced participation of family members in caring for the orchards, and subdivision of the areas because of inheritance threaten their continuity. Alongside this problematic situation, a lack of recognition of the benefits that Agroecosystems with Family Orchards (AEFO) provide for families leads to disinterest in preserving them. In addition, urban lifestyles exert pressure and result in these areas disappearing. For these reasons, families are beginning a process of abandonment and a consistent loss of the agroecological family orchard tradition.

In 2010, the Aichi Targets were proposed to reduce the loss of biological diversity; a second objective was for agricultural, aquaculture and forestry areas to be managed sustainably by 2020 , warranting biology diversity conservation (CBD, 2010). It is important to seek examples of practices, activities and systems in view of that aim. In practice, depending on the purpose and context of studies, different terms, definitions and interpretations have been generated in reference to family orchards, such as solar, backyard, yard, homegarden and others (Mariaca, 2012). Family orchards are defined as being an intrinsic association of multiple-use trees and shrubs with annual or perennial crops, and animals; they are a traditional agricultural production system managed with family labor (Nair, 1993). They also serve as a meeting place for social and cultural functions, relaxation and welfare for family members and neighbors (Cano et al., 2012). In addition, they provide tangible and intangible benefits of aesthetic and recreational value, based on the likes and preference of families (Lok, 1998).

The importance of this study is to highlight how families perceive the sociocultural and environmental benefits from family orchards for conserving biodiversity. The hypothesis of this study was that families have a positive perception of benefits obtained from these agroecosystems; they are conducive to practices, activities and techniques for biodiversity use. The aim was to analyze sociocultural and environmental benefits perceived by families owning family orchards in three municipalities of the Central Highlands of Mexico, through field observation and the application of semi-structured interviews with 180 heads of household.

\section{Theoretical framework}

\section{Social, environmental and sociocultural perception}

An analysis of attitudes identifies cultural, symbolic and cognitive components that support the patterns of society interaction with nature and their use (Bertoni and López, 2010). For Cunha et al. (2010) it is a relationship between the physical environment and reflexions with it, and the subjectivity of each person; answers or events are the results of local knowledge, based on these perceptions.

Social perceptions of the environment take form in cognitive systems that recognize the presence of opinions, beliefs, values and norms regarding the environment; these determine attitudes to nature conservation. They are the product of a perception and a social valuation that is integrated by affective and cognitive components linked on beliefs and attitudes of the inhabitants towards natural resources (Bertoni and López, 2010). For Fernández (2008) the study of environmental perception refers to the relationships that occur between humans and the environment, related to natural resource management; it is based on the existing knowledge about products extracted from it, it considers factors such as cultural aspects, ecological and climatological processes, and how these play a significant role in society.

For Vallejo et al. (2013) socio-cultural perception is a subjective understanding of social action, an understanding of human behavior from meanings and motives that are generated in the individual conscience. As a result of this, actions generate experience and knowledge, called "common sense", which guides actions and forms of interaction that are socially accepted and known by community members.

\section{Environmental benefits from family orchards. An agroecological strategy}

Current family orchards are the result of interactions between people, soil, water, animals and plants (Gaytán et al., 2001; Juan, 2013). They represent an ethnological heritage of first order with traditional knowledge passed down from generation to generation (Gispert et al., 2010). For centuries, their role has been to provide food for the family, but nowadays includes leisure and occupational aspects; the major contribution to the in situ conservation of many species and varieties of cultivated plants should not be forgotten (Rigat et al., 2009; Vilamajó et al., 2011). 
from one generation to another (García-Frapolli et al., 2008). For Massieu and Chapela (2007) traditional knowledge is closely related to cosmogony and the livelihoods of communities, because its purpose is to strengthen the values of the management of plants, seeds, animals and organization forms, as well as synchronization with solar and lunar cycles that guide crop sowing. Such knowledge is therefore essential for sustaining and preserving the important environmental role of subsistence farming (Vilamajó et al., 2011), which promotes diversity and accumulated knowledge about plants and living organisms interacting as part of the ecosystem.

According to Toledo (2005), traditional knowledge is a product of a network of relationships and practices that have developed over thousands of years within peasant and indigenous communities. It consists of beliefs (cosmos), knowledge that people keep in their minds, the structure or the elements of nature, the relationships established between them

Photo 2.

Water tank component in an AEFO. Photo J. García.

In this study, family orchards were conceived as agroecosystems, where families farm different plants and animals. AEFO is a traditional agricultural practice, integrating the following components: orchard, house, yard, water tank $^{1}$, fence, and areas for animal rearing, composting and growing vegetables. The orchard is usually located near the house, making care and maintenance activities easier for family members (Van der Wall et al., 2011; Mariaca, 2012; Chablé et al., 2015).

These traditional agroecosystems offer countless examples of sustainable agricultural practices: 1) They are based on polyculture planting; 2) They maximize crop safety using low levels of technology; 3) They have a limited environmental impact and are adapted to local conditions; 4) They contain a diversity of cultivated plants and adapted wild crops; 5) They do not depend as much on external inputs such as pesticides, fertilizers or artificial irrigation; 6) They make extensive use of renewable and locally available resources; 7) They have active nutrient recycling; 8) They conserve biological diversity; 9) They use production to meet local needs; 10) They are relatively independent of external economic factors; and 11) They are built on traditional knowledge and culture (Gliessman, 2002; Gliessman et al., 2007; Altieri, 2009; Sarandón and Flores, 2014).

\section{Cultural benefits from family orchards. Preservation and transmission of traditional knowledge}

The appropriation of nature is an expression of the implementation of a multiple-use strategy that responds to a rationality that is both ecological and economic. It is based on local ecological knowledge; it is a tradition that passes

\footnotetext{
${ }^{1}$ This means a construction made of cement containing water that people use for orchard irrigation, animal watering and cleaning operations.
}

and their useful application (corpus), as well as a set of productive practices, which combine in their knowledge system regarding their environment and their development in daily life (praxis).

The importance of preserving traditional knowledge associated with ecosystem management was recognized at the Biology Diversity Convention in 1992, mainly in agroecosystems, where the practices, beliefs, traditions and cosmovision of villagers contribute to natural resource conservation (Toledo, 2005; Calvet et al., 2014). People in AEFOs carry out processes for the management, adaptation and preservation of a wide range of agrobiodiversity, because they have supported a cultural identity for hundreds of years (Rigat et al., 2009; Garnatje et al., 2011; Calvet et al., 2014; Rivas, 2014).

\section{Social benefits from family orchards. A strategy for family food security}

According to the FAO, 842 million people are chronically hungry because they cannot afford adequate food. Worldwide, $70 \%$ of people live in the rural areas of developing countries (FAO, 2015). Production systems need to meet the food requirements in these areas (Rebollar et al., 2008; Gispert et al., 2010). One option is family farming, whose priority is its labor force, with limited access to land and capital resources, use of multiple survival strategies and access to income generation (AFAC, 2011). This concept includes groups of farmers and farming families engaged in producing food for self-consumption, providing food and many other products for food supplies. They are a starting point, like a recognition of traditional knowledge and ancestral wisdom of farming families (FAO, 2015). They combine tradition, innovation and science to promote the environment, fair relationships and a good quality of life. They also empower communities to take control of their food production needs, providing locally adapted systems that can be handled by them sustainably. These small production units are the key to food security (AFAC, 2011). 


\section{Material and methods}

The study area comprised three municipalities, in which 12 locations were chosen. The study population was families with a family orchard. The study was conducted from January to March 2015. The sample size was 180 heads of household aged 20 to 85 years; surveys were carried out at the home of each interviewee. The confidence level was $95 \%$, with a sampling error of $5 \%$. The "snowball" sampling method was used; this technique enables an informant network to be established (Santana et al., 2013).

After field work, consisting of systematic visits and direct observation in the field, 15 orchards were selected at each location and a semi-structured interview was conducted that identified management activities, practices and techniques, and family perceptions of AEFO benefits. The interview was approximately 30 minutes long; the purpose was to ascertain family socioeconomic conditions, the features of the terrain, family orchard characteristics, and the perception of social benefits derived from having a family orchard. The Statistical Program for Social Sciences (SPSS) was used to analyze the results.

This work consisted of five stages: a) Characterization of the locations; b) Features of the AEFOs in the study area; c) Characteristics of the families keeping up the family orchard tradition; d) Analysis of the sociocultural and environmental benefits from family orchards perceived by the interviewees; e) Analysis of the potential and problems of AEFOs.

Geographical characterization began with the delimitation of the study area. Physical characteristics such as the relief, climate, geology, soil and vegetation were analyzed. To determine socio-economic characteristics, data from the

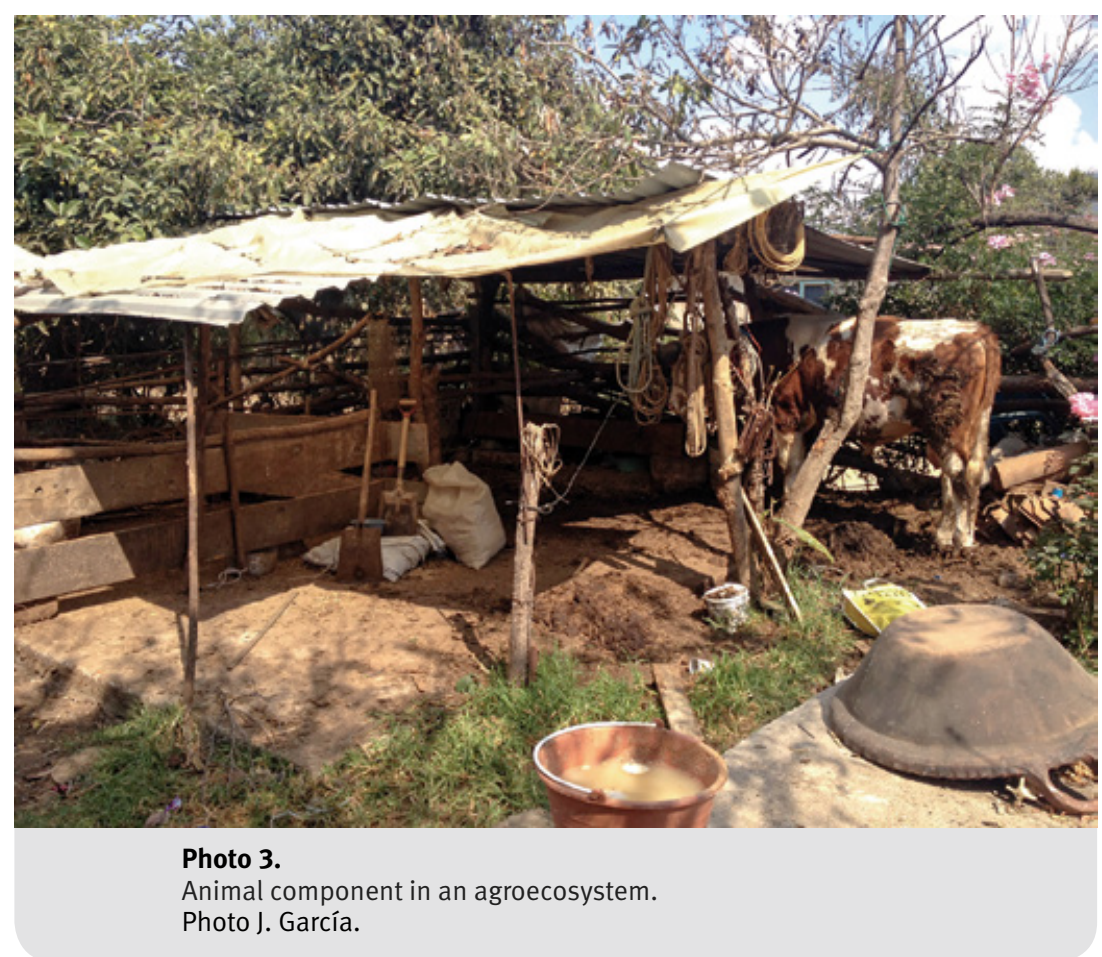

XII ${ }^{\text {th }}$ Population and Housing Census were processed (INEGI, 2010), making it possible to calculate the total population, the gender structure of the population, the education level, the Economically Active Population (EAP), the Economically Inactive Population (IEP), the population with access to medical care, and the characteristics of the houses.

The interviews helped to determine AEFO components, the practices implemented by the families, the area and location of the orchard in relation to the house, the animals present and protective fences. Related to the characteristics of the families, based on interviews, the main people responsible for maintenance were identified, along with the age of family members, the occupants in each house, the distribution of activities and the agroecological techniques applied to orchard care.

The social benefits analysis stage included aspects that were divided into three groups: 1) Ethical-aesthetics: this included variables of recreation, landscape and family organization for orchard maintenance. 2) Scientific-educational: this included an analysis of traditional knowledge, environmental education in agroecosystems and knowledge sharing between family members. 3) Aspects related to sustainability and food security, such as the strategy favored in aspects linked to human-nature relations and the food obtained.

For the analysis of AEFO potential and problems, Strengths, Weaknesses, Opportunities and Threats (SWOT) and a Frame Logic Analysis were used. Causes and effects that negatively affected the traditional practice were analyzed, but also their positive effects and importance for rural families.

\section{Results and discussion}

\section{Characteristics of the locations}

The study area was located in the Ecological Transition Zone (ecotone zone) of the State of Mexico, in which there are 24 municipalities. With the latitudinal and altitudinal gradients representing a region of geographical, ecological and socio-economic importance, being a transition zone between the Nearctic and Neotropical biogeographical realms, the area contained plants and animals representative of both realms. In the tradition of family orchards, there is an environmental, social and agroecological impact due to the association of plants, and to the traditional ancestral knowledge put into practice, allowing rural families to have a wide variety of trees and animals within the AEFO.

The locations analyzed belonged to the Malinalco, Tenancingo and Villa Guerrero municipalities, in the State of Mexico, Mexico. They were located between 180 48' 58" and 190 57' 07'" north latitude, 99ㅇ 38' $37^{\prime \prime}$ and $98^{\circ} 35^{\prime}$ 45" west longitude, with an 
approximate territorial area of $614.19 \mathrm{~km}^{2}$ (figure 1). The area displayed altitude differences, with the lowest points at Malinalco with 1,580 meters, and the highest at Villa Guerrero with 3,760 meters (INEGI, 2010). The latitudinal and altitudinal location of the study area was important because it promoted the existence of different climates, soil types and vegetation forms in these municipalities, which are conditions conducive to the traditional practice of family orchards.

The predominant climate was (A) Ca (w1) (w) (i') $)^{2}$ semiwarm, sub-humid with summer rainfall, an annual average temperature of $18.5^{\circ} \mathrm{C}$, with a maximum of $35.5^{\circ} \mathrm{C}$ and a minimum of $16.5^{\circ} \mathrm{C}$, with $1,305 \mathrm{~mm}$ of rainfall per year on average (García, 1982). In the areas of higher and lower altitude, other types of climate existed, e.g. semi-cold, temperate and warm. The study area revealed igneous and sedimentary rock types. The most frequent types of soil were andosols, vertisols, luvisols and haplic feozems. The predominant forms of vegetation were mixed pine-oak forest, pine forest and deciduous forest (López et al., 2012). The diverse climate, soil and vegetation forms prevalent in this region were of benefit to people in developing agricultural activities, achieving sociocultural adaptation and experimentation in family orchards with a vast agrobiodiversity of herbaceous plants, shrubs, trees and animals (Juan, 2013; White et al., 2013).

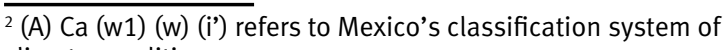
climate conditions.
Of the 12 locations included in the study area, three were municipal capitals and nine were rural communities. Its total population was 45,812 inhabitants, of which $52 \%$ women and $48 \%$ men. The population was divided into 11,269 minors, 30,387 adults and 4,156 people over 60 years old. With regard to schooling, $31 \%$ attended school, $26 \%$ did not attend school, $20 \%$ had a basic education, $18 \%$ had a post-basic education, and $5 \%$ were illiterate (INEGI, 2010). The formal education level was low, because people worked in agricultural activities, but these labor conditions helped to increase traditional knowledge of AEFOs.

The EAP in the locations amounted to 18,792 people and the EIP amounted to 14,868 people. Approximately $62 \%$ of the population had social security and $38 \%$ did not have that right as they worked in primary activities, had a low income and did not have access to medical care. These conditions led people to consider having a family orchard for the availability of dietary supplements and medicinal plants, highlighting the importance of traditional AEFO practices.

There was a total of 10,922 inhabited houses, i.e. $84 \%$ were occupied, with an average of 4 persons per household. In terms of utilities, $70 \%$ of homes had access to electricity, drinking water, public drainage, the rest suffered from a lack of services. The house construction material was $78 \%$ durable materials such as bricks, blocks and reinforced concrete, but they were not finished buildings (INEGI, 2010). Given the conditions, the marginality level of the zone could be classed as medium.

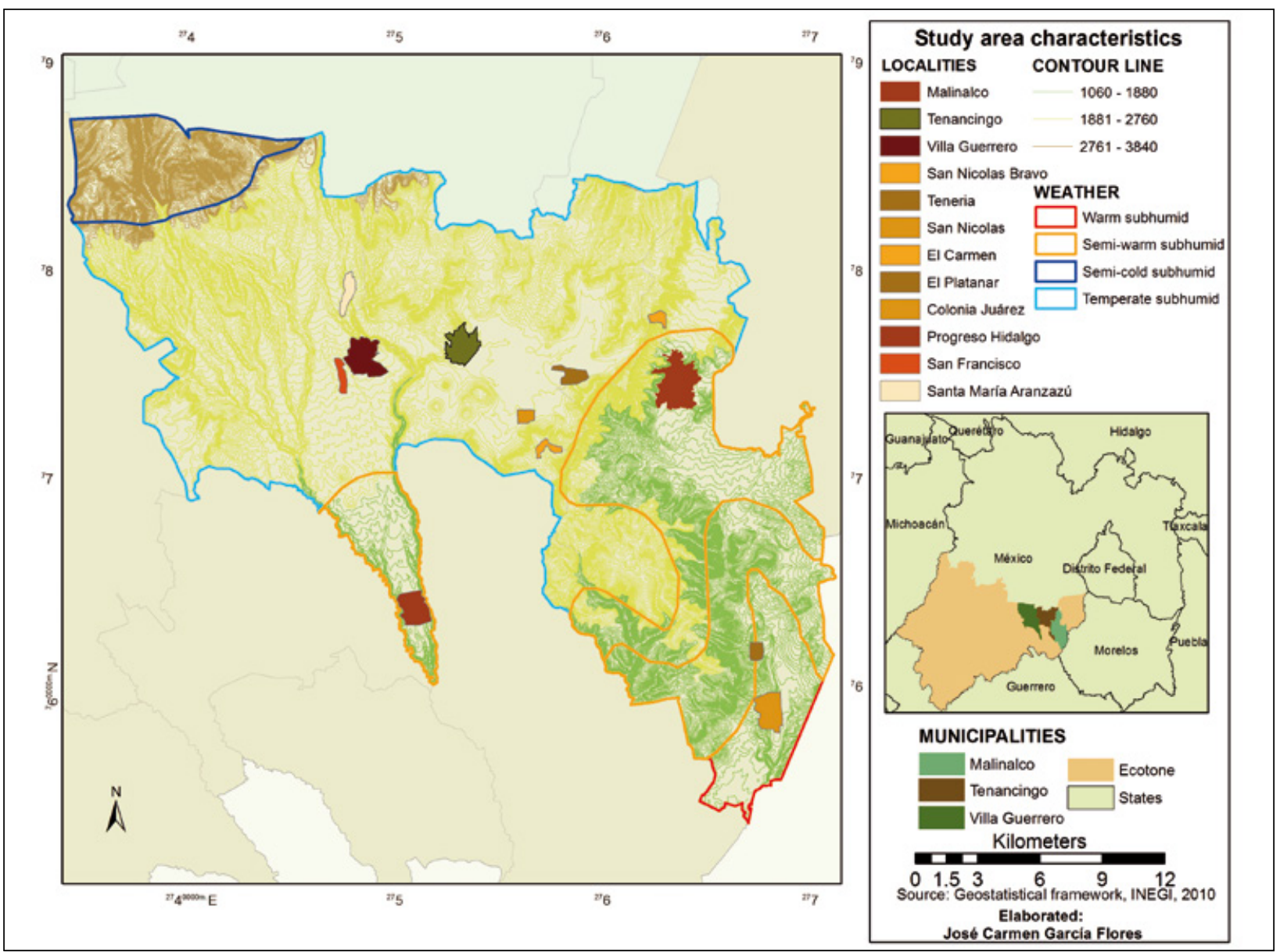

Figure 1.

Study area characteristics.

Source: Prepared based on the National Geostatistical Framework 2010 INEGI, 2015. 


\section{Characteristics of the agroecosystems with family orchards}

In these areas there were trees, shrubs, vegetables, and herbs that provided food products, condiments and medicinal plants. There was a diversity of species combinations of use for family consumption. The species diversity found in family orchards in these municipalities was: 134 trees or shrubs, 54 herbaceous or vegetable plants and 13 animals. The products obtained were fruits, leaves, stalks, flowers, sap, meat, milk and eggs; the main use was self-consumption (148 cases); through exchanges (58) and sales of surplus (38), the families complemented their diet with products they did not grow in their orchards. The AEFO provided species used for food (177 cases), condiments (69),

Table I.

Components of the Agroecosystems with Family Orchards (AEFO).

\section{Components}

Number of orchards with different components

\begin{tabular}{lr} 
House & 179 \\
\hline Yard & 136 \\
\hline Water tank & 134 \\
\hline Fence & 96 \\
\hline Animal rearing area & 75 \\
\hline Vegetable area & 21 \\
\hline Composting area & 18
\end{tabular}

Source: Prepared based on field work, 2015.

Table II.

Animals found in the Agroecosystems with Family Orchards (AEFO).

Animals ${ }^{a}$

Number of orchards where they were present

\begin{tabular}{lr} 
Chickens & 73 \\
\hline Hens & 64 \\
\hline Pigs & 30 \\
\hline Horses & 19 \\
\hline Rabbits & 18 \\
\hline Sheep & 11 \\
\hline Turkeys & 6 \\
\hline Cows & 6 \\
\hline Ducks & 5 \\
\hline Goats & 2
\end{tabular}

a Several animal species could be present in the same orchard.

Source: Prepared based on field work, 2015. medicines (69) and ritual purposes (45). Magaña (2012) mentioned that families use plants as a major strategy for their subsistence. Albuquerque et al. (2005) considered that the orchard provided products throughout the year. The results confirmed that $A E F O$ s are important for family diet, as a way of contributing to family food security.

Table I shows AEFO components. The most common are the house, yard and water tank, with less than a quarter of these agroecosystems having composting and vegetable growing areas. Colín et al. (2012) found that spatial organization depends on the characteristics of the owners' property, water availability and terrain slope and area. Santana et al. (2015) and White et al. (2013) related it to family growth and land tenure. This research found that families' health conditions, responsible ages and management knowledge were also related to the organization of the agroecosystem.

Based on field work and information from the interviews, it was obvious that people did not devote time and space to composting and growing vegetables, perhaps because they had no knowledge or habits of organic waste recycling as compost, and vegetable growing requires labor and the shade cast by trees affects vegetable growth. Only a few of the people interviewed had the knowledge and habit of growing vegetables. The most common practice observed was the placing of leaves, branches, fruit peel and kitchen waste directly at the foot of trees, as a way of decomposing organic matter (photo 1).

The area of the family orchards was $560 \mathrm{~m}^{2}$ in almost $40 \%$ of the cases, and between 561 and $1060 \mathrm{~m}^{2}$ in $40 \%$ of the cases, including various AEFO components (photo 2). The results of Guerrero (2007), Juan (2013) and Santana et al. (2015) in Central Mexican orchards showed an area under $400 \mathrm{~m}^{2}$, while in southeastern Mexico, Mariaca (2012) and Cahuich et al. (2014) reported over $800 \mathrm{~m}^{2}$. Colín et al. (2012), Mariaca (2012) and Cahuich et al. (2014) considered the area to be very variable, but with an average of $500 \mathrm{~m}^{2}$.

In terms of orchard location, 52\% were located in front of the house, $19 \%$ at the back, $16 \%$ and $13 \%$ to the left or right. Juan (2013) found that $32 \%$ were behind of house. In $81 \%$ of cases, the distance between these components was 2 to 7 meters. Both the location and distance made for easy monitoring and maintenance; in accordance with Rivas (2014) and the FAO (2015), this characteristic simplified crop protection and upkeep.

In terms of family orchard condition, $70 \%$ were well maintained, the reasons for preserving them being product consumption, house decoration, and the provision of construction and fuel materials. It is considered that $15 \%$ of all AEFOs are being lost, some of the reasons for this being that knowledge is not passed down from generation to generation in few families, properties are subdivided when children marry, urbanization and migration processes, according to Guerrero (2007), Van der Wall et al. (2011), Colín et al. (2012), White et al. (2013) and Chablé et al. (2015). In addition, some other factors were identified: indifference of the younger generations, lack of maintenance activities, and economic woes leading to portions of the properties being sold off.

Table II shows the animal species found to be part of the agroecosystems. Chickens, hens, pigs and, to a lesser extent, horses, rabbits and sheep were found to coexist in most family orchards; these species provided various 
Table III.

Type of fences in the Agroecosystems with Family Orchards (AEFO).

\begin{tabular}{l|rr}
\hline Type of fence & Number of family & orchards with fences \\
\hline Barbed wire or mesh & 77 & 42.8 \\
\hline Wall & 50 & 27.8 \\
\hline Live fence & 46 & 25.6 \\
\hline Stone fence (tecorral) & 7 & 3.9 \\
\hline Total & 180 & 100.0
\end{tabular}

Source: Prepared based on field work, 2015.

Table IV.

Schooling level of respondents.

\begin{tabular}{l|r|r}
\hline Schooling level & Number of respondents & Percentage \\
\hline Primary & 42 & \\
\hline Incomplete primary & 57 & 23.3 \\
\hline High school & 41 & 31.7 \\
\hline Incomplete high school & 1 & 22.8 \\
\hline Preparatory & 14 & 0.6 \\
\hline Incomplete preparatory & 2 & 7.8 \\
\hline Undergraduate & 6 & 1.1 \\
\hline No schooling & 17 & 3.3 \\
\hline Total & 180 & 9.4 \\
\hline
\end{tabular}

Source: Prepared based on field work, 2015.

products and services for the family, and they had limited space requirements (photo 3 ). As regards animal manure, half of the respondents said they left animal droppings where they were, almost a quarter of the owners placed them directly on trees and another quarter relocated them to their agricultural fields. This provides evidence of a general unawareness of the composting technique, but they used animal manure directly as an organic component of the soil.

Table III shows the type of fences found in the agroecosystems; almost three-quarters of them used inert materials and barbed wire; a quarter of the owners applied the agroecological technique of a live fence, and only a few of them use the traditional technique of stone fences (tecorral ${ }^{3}$ ).

The live fences in the AEFOs comprised plants that were mostly fruit trees interspersed with shrubs, barbed wire or fencing, as a way to take advantage of the space to obtain plants and food. Just under a quarter of fences had plants

\footnotetext{
${ }^{3}$ Tecorrals are stone stacks used to mark out ownership, sometimes with herbaceous plants growing up them.
}

with thorns, perhaps a little-used practice as a safety measure for children and animals, due to the proximity to housing.

Characteristics of families keeping up the family orchard tradition, activities and work division for handling AEFOs

Based on interviews in the 12 locations, $77 \%$ of respondents were female and $23 \%$ male. This may be because when the interviews were conducted the men had gone out to work and the women stayed at home. The interviewees ranged between 20 and 85 years old. The largest proportion of concentrated ages was between 31 and 60 years with $62 \%$ of respondents, and $18 \%$ were over 60 years old. The religion they mostly practiced was Catholicism (83\%), with the rest of the respondents holding different beliefs. The number of house occupants ranged from 1 to 19 people per household; in $85 \%$ of cases there were 2 to 7 people. In terms of schooling, $78 \%$ of respondents had a basic schooling level (table IV). Chablé et al. (2015) interviewed 160 owners in southeastern Mexico, 71\% were women. Garnatje et al. (2011) reported that orchard owners in the Catalan Pirineo were evenly women and men, mainly older adults with a basic educational level; those studies reported similar aging and schooling conditions to our results.

When asked about household income, only $6 \%$ of respondents agreed to answer, maybe due to the insecurity they perceived, or the variable income making it difficult to calculate. They earned from 1,800 to 2,900 pesos monthly, approximately 100 to 161 dollars as overall formal family income. In addition, the family orchards generated income because the owners sold fruits, animals and plants, which had a high value on the regional market. According to Toledo et al. (2008), Colin et al. (2012), Juan (2013), Chablé et al. (2015) and Santana 
et al. (2015), it is a strategy of multiple uses of resources and maintenance for rural families, in a low employment and low income context. The main occupation was a housewife with $67 \%$ of cases, followed by $13 \%$ for farming activities (table V). For family orchards in the Mazahua zone, Guerrero (2007) reported similar incomes and occupations.

Just over half of respondents were natives of the town, with an average of between 27 and 50 years of residence; they liked the zone's favorable climate. In $52 \%$ of homes there was a family which had lived with its orchard since birth, with an average of 18 to 41 years growing their family orchards.

As regards the time devoted to that task, $79 \%$ of respondents spent between 2 and 8 hours per week, in which they undertook maintenance activities (photo 4). Only 1\% spent more than 24 hours per week, as these agroecosystems did not require as much care as an ornamental and decorative garden. According to Nair (1993), in these systems care is provided with the participation of the whole family.

Men carried out various activities: pruning trees, as well as composting work, weeding by uprooting or cutting grasses, pest control by chemical or natural preparations,

\section{Table V.}

Occupation of respondents.

\begin{tabular}{l|c|c|} 
Occupation & Number of respondents & Percentage \\
\hline Housewife & 121 & 67.2 \\
\hline Peasant & 24 & 13.3 \\
\hline Dealer & 17 & 9.4 \\
\hline Crafts & 12 & 6.6 \\
\hline Unemployed & 6 & 3.5 \\
\hline Total & 180 & 100.0 \\
\multicolumn{1}{r}{ Source: Prepared based on field work, 2015.} & \\
\hline
\end{tabular}

and painting the base of tree trunks with a mixture of prickly pear, lime and water, to prevent insects and pests from climbing them. Men had the knowledge to carry out this work, which also involved physical exertion (table VI).

On the other hand, women were responsible for cultivation in the family orchards, because they stayed at home longer, so they spent part of the time taking care of the plants. The activities attributed to women's responsibilities included planting trees, cleaning family orchards by sweeping up the fallen leaves of trees, and watering the plants, along with harvesting. This is because women were responsible for providing food, so they chose new trees to plant and decided which fruits could be used to supplement the family diet (table VII).

Weeding was carried out in 169 family orchards, manually, with a machete ${ }^{4}$, a hoe or by tearing off the grass by hand; in 11 cases brush cutting equipment was used and on 4 occasions herbicide was used. Manual weeding was carried out because it was a very selective activity, due to complex species associations, which are a feature of agroecosystems. The owners used different sources of water to water their family orchards. In 134 family orchards they used water from the municipal drinking water systems, and in 15 cases water from washing dishes and clothes was reused; this may be attributed to water distribution for the various activities related to their use. The most common irrigation technique used was a bucket (105 cases), perhaps because women carried out this activity, consequently they managed and provided water from inside the home.

The frequency with which the owners of family orchards produced compost amounted to $41 \%$ of the agroecosystems; they reserved an area of the property for this practice of processing organic matter. The organic materials

${ }^{4}$ Metal tool used to cut branches, stems or grasses.

Table VI.

Activities of the father with help from other members.

\begin{tabular}{|c|c|c|c|c|c|}
\hline In charge & Pruning & Natural fertilizers & Weeding & Pest control & Liming of trees \\
\hline Father & 108 & 32 & 100 & 32 & 31 \\
\hline Mother & 23 & 13 & 26 & 10 & 4 \\
\hline Son & 18 & 13 & 31 & 6 & 12 \\
\hline Daughter & 1 & 0 & 5 & 0 & 1 \\
\hline Grandfather & 4 & 1 & 0 & 0 & 1 \\
\hline Grandson & 2 & 0 & 1 & 1 & 2 \\
\hline Total & 156 & 59 & 163 & 49 & 51 \\
\hline
\end{tabular}


Table VII.

Activities of the mother with help from other members.

\begin{tabular}{l|c|c|c|c|}
\hline & Tree planting & Cleaning family orchard & Irrigation & Crop products \\
\hline Mother & 32 & & 104 & 87 \\
\hline Father & 24 & 32 & 42 & 52 \\
\hline Son & 8 & 34 & 18 & 10 \\
\hline Daughter & 3 & 8 & 8 & 6 \\
\hline Grandfather & 2 & 8 & 0 & 1 \\
\hline Grandmother & 1 & 0 & 4 & 0 \\
\hline Grandson & 1 & 4 & 0 & 0 \\
\hline Total & 71 & 0 & 176 & 156 \\
\hline \multicolumn{1}{r}{ Source: Prepared based on field work, 2015. } & 186 & & \\
\hline
\end{tabular}

\begin{tabular}{|c|c|}
\hline \multicolumn{2}{|c|}{$\begin{array}{l}\text { Table VIII. } \\
\text { Materials used for compost. }\end{array}$} \\
\hline Compost material & $\begin{array}{l}\text { Number of times } \\
\text { materials used }\end{array}$ \\
\hline Tree leaves & 68 \\
\hline Domestic waste & 42 \\
\hline Manure & 31 \\
\hline Weeding and pruning & 21 \\
\hline Ash & 15 \\
\hline \multicolumn{2}{|c|}{ Source: Prepared based on field work, 2015.} \\
\hline
\end{tabular}

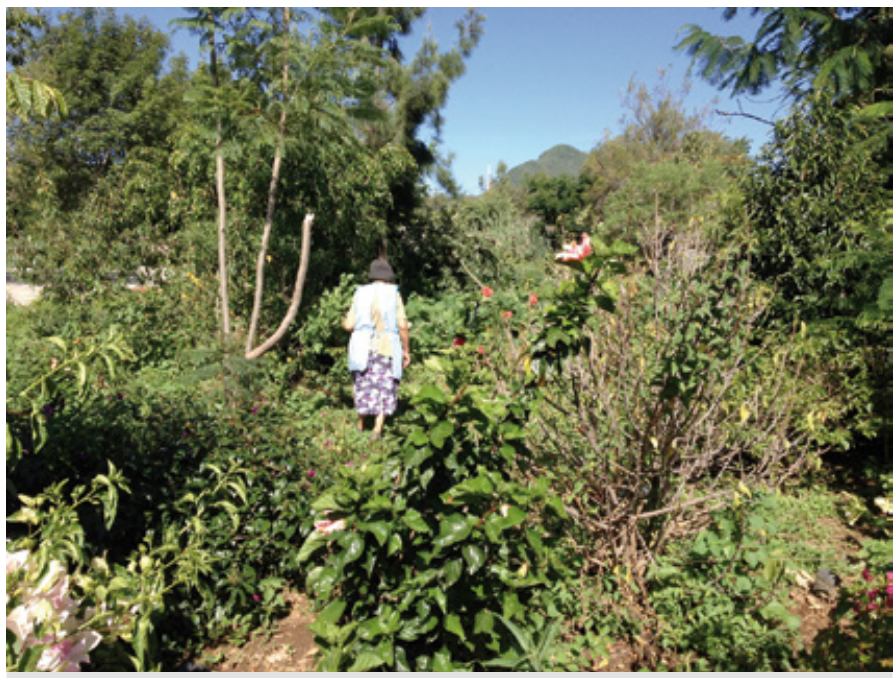

Photo 4.

Maintenance activities by women in a family orchard. Photo J. García. used were tree leaves, household waste, manure, grass and ashes (table VIII). Compost was applied to the orchard in 52 cases, while on 18 occasions it was carried to the agricultural plot. It is clear that composting did not exist in many family orchards, probably because the owners were unaware of the benefits of composting techniques and did not spend time in processing it.

A strategy applied by families to use organic waste from the kitchen was feeding animals in 62 cases, as a cheap strategy to maintain small animals. Fifty-four respondents answered that waste was deposited in a garbage truck.

\section{Sociocultural and environmental benefits derived from family orchards}

One meaningful question put to the respondents was why the family had an orchard, in order to bring out the importance an AEFO represented to them. Table IX shows the motives for having and caring for family orchards. The main reason for having them was to meet food requirements; this was due to the number and variety of trees and plants growing in family orchards and providing foods that complemented their family diet. In relation to ethical - aesthetic aspects, families quoted the use of these agroecosystems for recreation purposes, family meetings, leisure time and social events. Cano et al. (2012) also reported social and cultural functions.

Associated with sustainability and food security objectives, the products and services provided by the agroecosystems included food products that the families consumed from the AEFO (perceived in 177 cases); family orchards gave them fruits, but also medicinal plants for health care, condiments for food preparation. Less often they took advantage of plant leaves, vegetables, stalks, eggs and milk, showing that it was a system from which a variety of food and medicinal products were obtained.

The main use made of the AEFO by the family was food production. However, the space was also used for other purposes, such as carrying out recreational and decorative 
Table IX.

Motives for having an Agroecosystem with Family Orchards (AEFO).

\begin{tabular}{l|r|l|c} 
Reasons & Replies & Other uses & Replies \\
\hline Meet food needs & 105 & Recreation & 86 \\
\hline Shade & 67 & Ornamental & 78 \\
\hline Nice weather & 46 & Family meetings & 42 \\
\hline Income generation & 8 & Leisure time & 12 \\
\hline & & Social events & 11 \\
\hline
\end{tabular}

Source: Prepared based on field work, 2015.

Table X.

Sociocultural benefits and environmental services that owners and communities receive from the Agroecosystems with Family Orchards (AEFO).

\section{Goods and services}

Shade contribution

Animal shelter

130

124

Maintains humidity

88

Animal feed

71

Stick or branch supports for vegetable

Provides leaves for composting or animal feed

62

Fence branches

60

Repels pests

38

To Avoid grass growth

30

Prevents soil erosion

20

12

Source: Prepared based on field work, 2015.

activities as listed in table IX. Both recreation and decoration highlight the importance of these agroecosystems for families in obtaining enjoyment, linked to ethical-aesthetic aspects (photo 5).

Table $X$ shows some of the social and cultural benefits and environmental services that people perceived they obtained from family orchards; the most frequently mentioned were their contribution as a source of shade and an animal shelter, followed by maintaining humidity and food for animals. But the interviewees identified various uses that they made in other activities, such as functions related to different traditional ecological techniques that they had preserved and which were linked to varied environmental services that promoted productivity and quality of life. For Garnatje et al. (2011) and Calvet et al. (2014) these agroecosystems maintain traditional ecological knowledge, since they contribute directly or indirectly to the conservation of biological diversity.
The families also perceived that the AEFO provided them with various sociocultural benefits, such as the provision of shade (130 cases) with two main functions: creating a comfortable home microclimate, and as a way of retaining moisture in the agroecosystem; these benefits were achieved by intercropping trees, shrubs and herbaceous plants to maintain soil cover and prevent rapid evapotranspiration. They served as an animal shelter (124 cases), not only for wildlife, but also for raising chickens, which at night were kept safe and protected in the branches of trees to avoid being attacked by predators. The use of branches as supports refers to the fact of sowing plants at the foot of a tree, such as species of climbing vegetables like squash (Cucurbita pepo L.) or chayote (Sechium edule Sw.), so that the tree serves as a support for growth and production (photo 6). In terms of these functions Calvet et al. (2014) reported that in these agroecosystems, families applied traditional knowledge for the management, use and care of biocultural diversity.

In these agroecosystems, tree leaves were used for three purposes: firstly leaving them where they fell as ground cover to retain moisture, secondly for feeding small animals such as rabbits, and thirdly composting them for organic fertilizer. Branches in some family orchards were used to delimit the property. In some family orchards, the owners found that growing certain plants could be useful as repellents, such as rue (Ruta graveolens L.). Among other benefits, it was understood that the accumulation of leaves and the presence of trees and shrubs could even prevent the growth of undesired grasses and erosion processes.

The owners' perception of the benefits derived from their family orchards revealed that 121 respondents had a positive opinion about the products obtained and used for household consumption, 70 said they contributed to their health through the healthy products consumed, which were produced without agrochemicals. They also perceived clean air generation and a variety of medicinal plants that helped them to treat illness; they remarked that the existence of the plants favored their family's well-being. They highlighted economic benefits from product sales and exchanges, providing money that complemented the family diet in 15 cases.

In terms of scientific-educational benefits, most owners considered that family orchards provided recreational activities, taught their children to take care of nature and share their knowledge with other family members. In 127 cases, the main reason why people were responsible for maintaining the family orchards was because they loved nature and enjoyed it. Forty-seven of them mentioned obtaining food as their motivation; just over $25 \%$ of respondents considered 


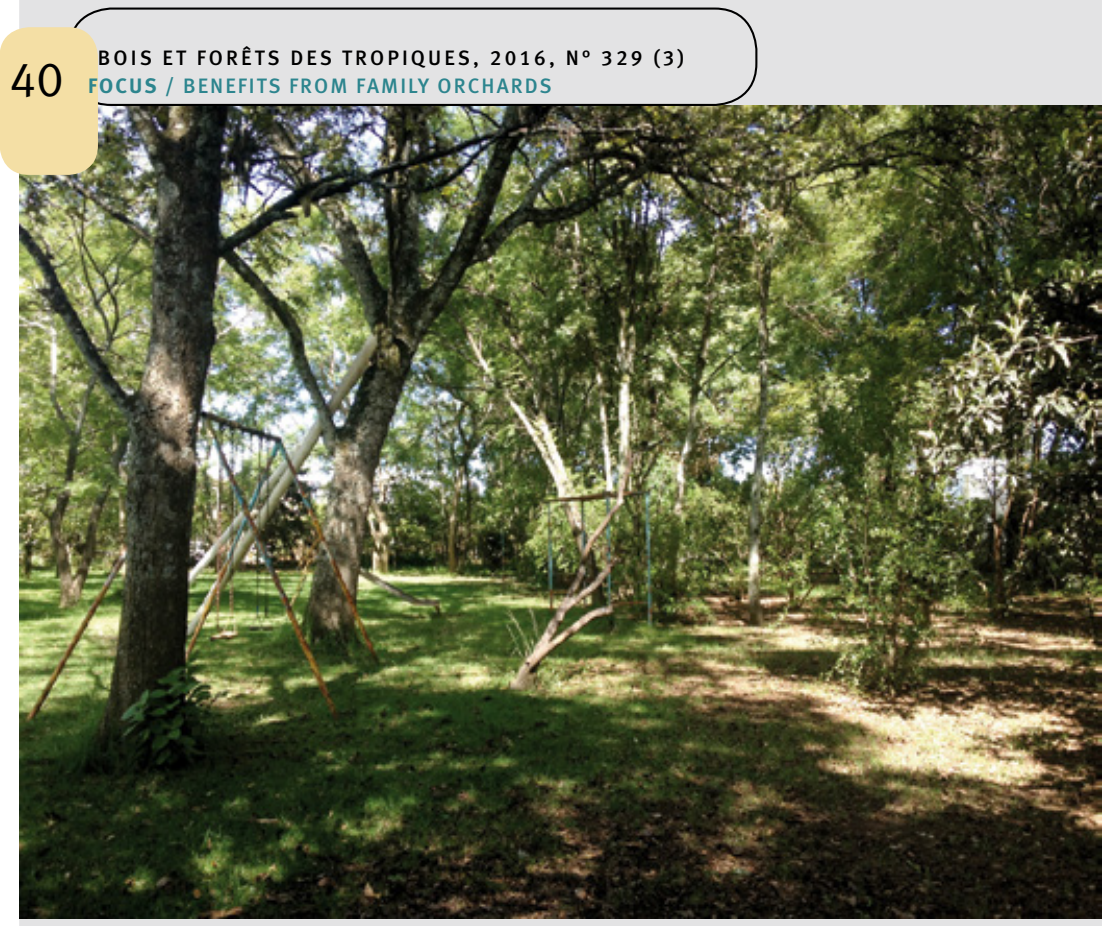

Photo 5.

Recreational use of family orchard. Photo J. García.

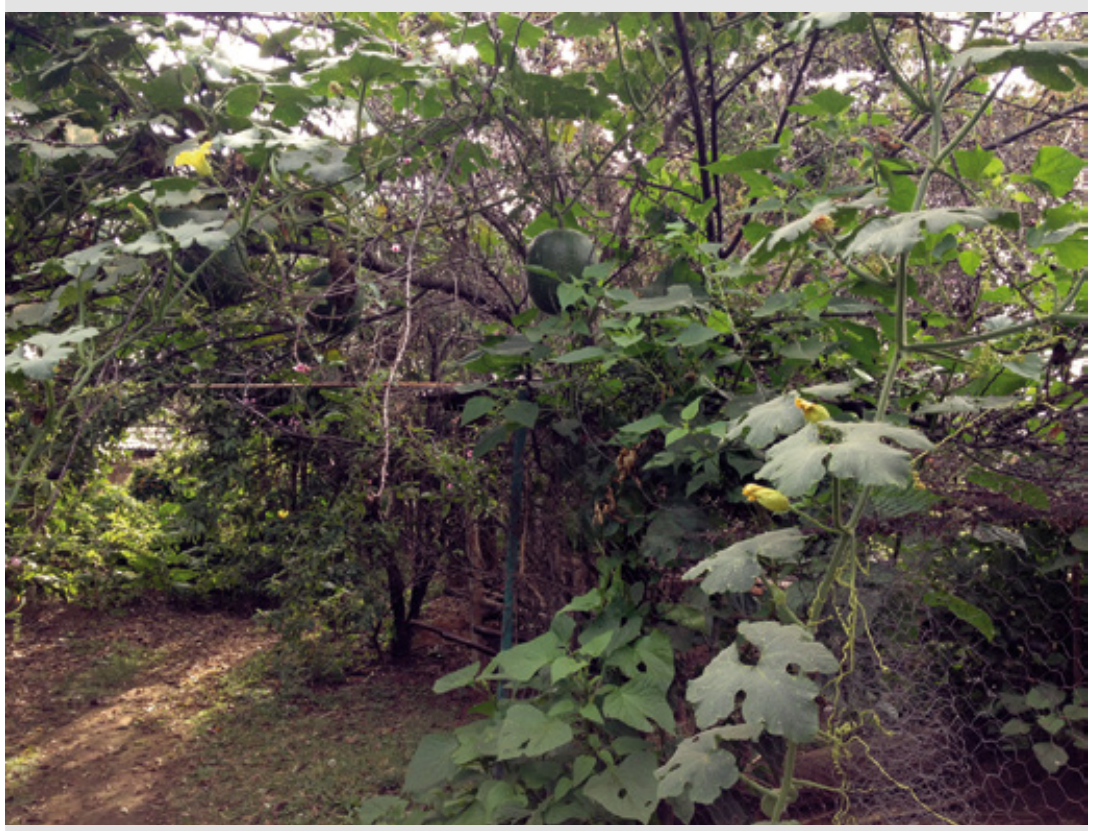

Photo 6.

Growing vegetables using tree branches as supports.

Photo J. García.

taking care of family orchards was a recreational activity. Lok (1998) affirmed that they provide aesthetic benefits. They also perceived ethical-aesthetic benefits offered by the presence of birds and other wildlife that came to eat fruits or to sleep at night.

The traditional knowledge that families maintained and reproduced in AEFOs, had led them to preserve traditional crop management, which had been acquired through the empirical practice of these activities and through continuous and systematic observation of natural processes functioning in the agroecosystem. As regards the knowledge they possessed for maintaining the family orchards, $64 \%$ of respondents received it from their parents, because it was a traditional practice passed down from generation to generation, from parent to child. The transmission of knowledge was shared by $53 \%$ of owners. They shared that knowledge with their children (72 cases), with grandchildren (12) and with neighbors (9). Ninety percent of them had not received any technical assistance for agroecosystems maintenance, as it was considered traditional knowledge in these municipalities. However, 50\% of families were interested in receiving training to improve the condition of their family orchards.

\section{Potential and problems of family orchards}

Identifying social benefits means considering family interactions and relationships with other people. More than two thirds of the respondents believed that family orchards allowed conviviality between family members and neighbors; this corroborated the importance of family orchards for family integration and social cohesion. The ways in which family orchards enabled people to relate were mostly linked to the exchanging of products and knowledge sharing.

There were a few problems associated with family orchards. In 11 cases, animal incursions were mentioned; this may have been because the AEFOs often had barbed wire fences, through which small animals could enter and affect the agroecosystem. Invasion by neighbors' house plants was mentioned in 10 cases, along with falling leaves, or branches affecting others' property, or fear that a tree might affect someone's house. However, very few family orchard owners had problems with their neighbors due to the presence and maintenance of their agroecosystem; most did not give rise to disputes because AEFOs were an ancient tradition that they had practiced for many years.

Among the most common problems for the maintenance and persistence of AEFOs, 103 families considered the lack of space as a major obstacle when property divisions occurred, to build homes for their married children. In 62 cases, a lack of knowledge and a lack of time were limiting factors for continuing the tradition of family orchards. These social conditions affected the area and threatened the traditional practice of family orchards. 


\section{Conclusions}

Through the management of family orchards, farming is developed because it forms part of traditional knowledge, traditions and beliefs about the use of objects for plant protection and the use of plants to treat respiratory and digestive diseases and diseases of a cultural nature. In these agroecosystems, people have made local adaptations that contribute to the conservation of trees, shrubs, herbaceous plants and animals in situ, resulting in benefits and traditional knowledge.

Agroecosystems with Family Orchards highlight the economic benefits for families as surplus products from the orchards are sold or exchanged, contributing to family income in seasons when jobs are scarce, although the main destination for AEFO products is home consumption. There is alternative income generation for families, derived from the sale of surplus produce that enhances family household savings driven by self-consumption.

Being a traditional practice where people participate and natural ecosystem processes are imitated, it is possible to maintain biodiversity over time, and ensure its preservation. This allows family integration through work distribution for AEFO management, and even relations with other families through the exchange of products such as fruit, seeds, leaves and plants.

\section{Acknowledgements}

The Authors are grateful to the Science and Technology National Council (CONACYT) for financing, and to the State of Mexico Autonomous University (UAEM) for the institutional support of the study. We should like to thank all the people who took part in the interviews and provided information.

\section{References}

AFAC (Agricultura Familiar Agroecológica Campesina), 2011. Agricultura familiar agroecológica campesina en la comunidad andina. Una opción para mejorar la seguridad alimentaria y conservar la biodiversidad. Bolivia, Colombia, Ecuador, Perú. Secretaría General de la Comunidad Andina, 54 p. http://www.comunidadandina.org/ Upload/2011610181827revista agroecologia.pdf

Albuquerque U. P., Andrade L. H. C., Caballero J., 2005. Structure and floristics of homegardens in Northern Brazil. Journal of Arid Enviromental, 62: 491-506.

Altieri M., 2009. Vertientes del pensamiento agroecológico: fundamentos y aplicaciones. SOCLA, Medellín, Colombia, $65 \mathrm{p}$.

Altieri M., Nicholls C., 2013. Agroecología: única esperanza para la soberanía alimentaria y la resiliencia socioecológica. Agroecología, 7 (2): 65-83.
Bertoni M., López M., 2010. Percepciones sociales ambientales. Valores y actitudes hacia la conservación de la Reserva de Biosfera “Parque Atlántico Mar Chiquita” Argentina. Estudios y Perspectivas en Turismo, 19: 835-849.

Cahuich D., Huicochea L., Mariaca R., 2014. El huerto familiar, la milpa y el monte Maya en las prácticas rituales y ceremoniales de las familias de X-Mejía, Hopelchén, Campeche. Relaciones, 35 (14): 157-184.

Calvet L., Garnatje T., Parada M., Vallés J., Reyes V., 2014. Más allá de la producción de alimentos: los huertos familiares como reservorios de diversidad biocultural. Ambiente, 107: 1-15.

Cano M. R., De la Tejera B., Casas A., García R. B., 2010. Migración rural y huertos familiares en una comunidad indígena del centro de México. Botanical Sciences, 90 (3): 287-304.

CBD (Convenio sobre la diversidad biológica), 2010. Las Metas de Aichi para la diversidad biológica. Convenio sobre la diversidad biológica, 1 p. [Online] https://www.cbd.int/ sp/targets/

Chablé R., Palma D., Vázquez C., Ruiz O., Mariaca R., Ascencio J., 2015. Estructura, diversidad y uso de las especies en huertos familiares de la Chontalpa, Tabasco, México. Ecosistemas y Recursos Agropecuarios, 2 (4): 23-39.

Colín H., Hernández A., Monroy R., 2012. El manejo tradicional y agroecológico en un huerto familiar de México, como ejemplo de sostenibilidad. Etnobiología, 10 (2): 12-28.

Cunha C., Sobral I., Jane L., 2010. Percepción ambiental como estrategia para el ecoturismo en unidades de conservación. Estudios y Perspectivas en Turismo, 19: 1121- 1135. FAO (Organización de las Naciones Unidas para la Alimentación y la Agricultura), 2005. Los medios de vida crecen en los huertos familiares. Diversificación de los ingresos rurales mediante las huertas familiares. Roma, $21 \mathrm{p}$.

FAO (Organización de las Naciones Unidas para la Alimentación y la Agricultura), 2015. El estado mundial de la agricultura y la alimentación. La innovación en la agricultura familiar. Roma, 175 p.

Fernández Y., 2008. ¿Por qué estudiar las percepciones ambientales? Una revisión de la literatura mexicana con énfasis en Áreas Naturales Protegidas. Espiral, Estudios sobre Estado y Sociedad, 14 (43): 179-202.

García E., 1982. Modificaciones al sistema de clasificación climática de Köppen. Instituto de Geografía. UNAM, 252 p.

García-Frapolli E., Toledo V., Martínez-Alier J., 2008. Apropiación de la Naturaleza por una comunidad Maya-Yucateca: Un análisis económico-ecológico. Revista Iberoamericana de Economía Ecológica, 7: 27-42.

Garnatje T., Calvet L., Parada M., Rigat M., Vallés J., Reyes V., 2011. Los huertos familiares del pirineo. Aproximaciones etnobotánicas y etnoecológicas del Pirineo Catalán. Métode, 72: 73-76.

Gaytán C., Vibrans H., Navarro H., Jiménez M., 2001. Manejo de huertos familiares periurbanos de San Miguel Tlaixpan, Texcoco, Estado de México. Boletín de la Sociedad Botánica de México, 69: 39-62. 
Gispert Cruells M., Vales A. M., Vilamajó Alberdi D., 2010. Els horts familiars de Méxic i de Cuba. Interrelació existent entre l'entorn natural, la societat i les identitats culturals a l'Amèrica tropical. Revista d'Ethnologia de Catalunya, 36: 104-115.

Gliessman S. R., 2002. Agroecología: Procesos ecológicos en agricultura sostenible. Costa Rica, Sleeping Bear Press, $359 \mathrm{p}$.

Gliessman S. R., Rosado-May F. J., Guadarrama-Zugasti C., Jedlicka J., Cohn A., Mendez V. E., Cohen R., Trujillo L., Bacon C., 2007. Agroecología: promoviendo una transición hacia la sostenibilidad. Ecosistemas, 16 (1): 13-23.

GTZ (Agencia Alemana de Cooperación Técnica), 2008. Huertos familiares: tesoros de diversidad.

Guerrero A., 2007. El impacto de la migración en el manejo de solares campesinos, caso de estudio La Purísima Concepción Mayorazgo, San Felipe del Progreso, Estado de México. Investigaciones Geográficas, 63: 105-124

INEGI (Instituto Nacional de Estadística, Geografía e Informática), 2010. Marco Geoestadístico Nacional. INEGI, México. http://www.inegi.org.mx/geo/contenidos/geoestadistica/m g 4.aspx

INEGI (Instituto Nacional de Estadística, Geografía e Informática), 2010. XII Censo de Población y Vivienda 2010. Consultado el 15 de marzo de 2015. INEGI. http://www. inegi.org.mx

Juan J., 2013. Los huertos familiares en una provincia del subtrópico Mexicano. Análisis espacial, económico y sociocultural. Ed. Eumed, 136 p. http://www.eumed.net/ libros-gratis/2013/1251/index.htm

López E., López J. A., Beltrán A., Aguilera L., 2012. Composición de la flora arbórea en el Área Natural Protegida Tenancingo-Malinalco-Zumpahuacán, Estado de México, México. Polibotánica, 34: 51-98.

Lok R., 1998. El huerto casero tropical tradicional en América Central. In: Lok R. (Ed.). Huertos Caseros Tradicionales de América Central: características, beneficios e importancia, desde un enfoque multidisciplinario. CATIE, Turrialba, Costa Rica, p. 07-28.

Magaña M., 2012. Etnobotánica de las plantas medicinales en los huertos familiares de Tabasco. In: El huerto familiar del sureste de México. Secretaría de Recursos Naturales y Protección Ambiental del Estado de Tabasco. ECOSUR, p. 176-196.

Mariaca R., 2012. El huerto familiar del sureste de México. Secretaría de Recursos Naturales y Protección Ambiental del Estado de Tabasco. ECOSUR, 551 p.

Massieu Y., Chapela F., 2007. Valoración de la biodiversidad y el conocimiento tradicional: ¿un recurso público o privado? In: Concheiro L. and López F. (Coord.). Biodiversidad y conocimiento tradicional en la sociedad rural: entre el bien común y la propiedad privada. CEDRSSA, México, p. 339-373.

Nair P. K., 1993. Homegardens. In: Nair P. K. An introduction to agroforestry. Kluwer Academic Publishers, The Netherlands, p. 85-97.
Rebollar S., Santos V., Tapia A., Pérez C., 2008. Huertos familiares. Una experiencia en Chancah Veracruz, Quintana Roo. Polibotánica, 25: 135-154.

Rigat M., Garnatje T., Vallés J., 2009. Estudio etnobotánico del alto valle del río Ter (Pirineo catalán): resultados preliminares sobre la biodiversidad de los huertos familiares. In: Llamas F. and Acedo C. (Coord.). Botánica pirenaico-cantábrica en el siglo XXI, Universidad de León, España, p. 399-408.

Rivas G., Rodríguez A., 2013. El huerto familiar: algunas consideraciones para su establecimiento y manejo. Una forma de contribuir a la seguridad alimentaria. CATIE, Costa Rica, 38 p.

Rivas G., 2014. Huertos familiares para la conservación de la agrobiodiversidad, la promoción de la seguridad alimentaria y la adaptación al cambio climático. Ambiéntico, 243: 4-9.

Santana M., Parra M., Salvatierra E., Arce A., Montagnini F., 2013. Políticas turísticas, actores sociales y ecoturismo en la península de Yucatán. Economía, Sociedad y Territorio, 13 (43): 641-674.

Santana M., Navarrete D., Mateo J., 2015. Riqueza de especies en huertos familiares caseros de tres municipios de la región Otomí Tepehua, Hidalgo, México. In: Montagnini F., Somarriba E., Murgueitio E., Fassola H., Eibl B. (Coord.). Sistemas agroforestales. Funciones productivas, socioeconómicas y ambientales. CATIE, Costa Rica, p. 405-422.

Sarandón S., Flores C., 2014. Agroecología: bases teóricas para el diseño y manejo de Agroecosistemas sustentables. Edulp, Argentina, $466 \mathrm{p}$.

Toledo V. M., 2005. La memoria tradicional: la importancia Agroecológica de los saberes locales. Leisa, 20 (4): 16-19.

Vallejo B., Osorio M., Ramírez I., Nava G., Franco S., 2013. Análisis social sobre los habitantes de la comunidad de La Peñuela, Parque Nacional Nevado de Toluca, México. Estudios y Perspectivas en Turismo, 22 (3): 425-449.

Van der Wal H., Huerta E., Torres A., 2011. Huertos familiares en Tabasco: Elementos para una política integral en materia de ambiente, biodiversidad, alimentación, salud, producción y economía. Secretaria de Recursos Naturales y Protección Ambiental, Gobierno del Estado de Tabasco y ECOSUR, $149 \mathrm{p}$.

Vilamajó D., Gispert M., Vales M., Gonzalez A., Rodríguez H., 2011. Los huertos familiares como reservorios de recursos fitogenéticos arbóreos y de patrimonio cultural en Rayón, México y El Volcán, Cuba. Etnobiología, 9 (1): 22-36.

White L., Juan J., Chávez C., Gutiérrez J., 2013. Flora medicinal en San Nicolás, municipio de Malinalco, Estado de México. Polibotánica, 35: 173-206. 